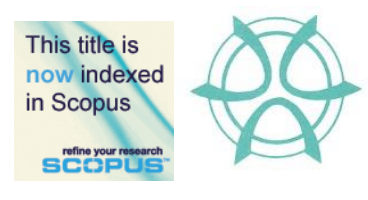

PLANNING MALAYSIA:

Journal of the Malaysian Institute of Planners

VOLUME 16 ISSUE 1 (2018), Page 397 - 404

\title{
POLICY AVAILABLE AND SUSTAINABLE WATERFRONT DEVELOPMENT
}

\author{
Azlina Md. Yassin ${ }^{1}$, Md. Asrul Nasid Masrom², Mohd. Najib Mohd. Razali ${ }^{3}$, \& \\ Yasmin Mohd. Adnan ${ }^{4}$ \\ ${ }^{1,2}$ Faculty of Technology Management and Business \\ UNIVERSITI TUN HUSSEIN ONN MALAYSIA \\ ${ }^{3}$ Faculty of Engineering and Geoinformation \\ UNIVERSITI TEKNOLOGI MALAYSIA \\ ${ }^{4}$ Faculty of Built Environment \\ UNIVERSITI MALAYA, MALAYSIA
}

\begin{abstract}
Waterfront redevelopment emerged in the 1970s. Since then, numerous waterfront areas went through transitions from abandoned spaces to commercial, residential and recreational areas. The transformation symbolizes the independent city states' efforts to remake themselves for the 21 st century. However, due to constraints such as ineffective governance as well as inadequate federal, state and municipal planning guidelines, the waterfronts faced problems such as environmental degradation, crime and flooding. Although some waterfront development projects remained profitable due to good public access, many did not. This paper intends to identify and evaluate the current regulations and guidelines towards sustainable waterfront development in Malaysia. The findings were based on the questionnaires mailed and e-mailed to property development companies listed under Bursa Malaysia in Malaysia. The findings identified ten laws and regulations related to waterfront development in Malaysia such as; the National Land Code 1965, the Town and Country Planning Act 1976, and the Environment Quality Act 1974. In terms of the sufficiency of those regulations and guidelines for controlling waterfront development, more than half of respondents claimed that Malaysia did not have sufficient regulations to control waterfront development and the regulations were weakly enforced in Malaysia. The findings indicated that the government and the policy makers need to improve regulations for waterfront development.
\end{abstract}

Keyword: enforcement, laws and regulation, waterfront, waterfront development 
Azlina Md. Yassin, Md. Asrul Nasid Masrom, Mohd. Najib Mohd. Razali, \& Yasmin Mohd. Adnan

Policy Available and Sustainable Waterfront Development

\section{INTRODUCTION}

The growth of urban areas is a sign of a healthy Malaysian economy. The rapid development and urbanization encouraged the waterfront development for recreational use and mixed-use development. To date, demands on waterfront properties are booming even when offered at high prices, as more and more people wish to live close to the water for recreation and aesthetic reasons (Yassin, 2012). However, the implementation of these waterfront projects is driven more by investment needs rather than by community and environmental needs. Waterfront development creates negative impact environmentally and socially such as water pollution and crime (Ali \& Nawawi, 2009; Latip, Heath, Shamsuddin, Liew, \& Vallyutham, 2010). Therefore, this paper aims to identify and evaluate the current regulations and guidelines relating to waterfront development in Malaysia. A quantitative research strategy with survey questionnaire approach was adopted in this research. The findings of the study discuss on the planning of waterfront development to improve future practices of waterfront development in Malaysia.

\section{WATERFRONT DEVELOPMENT}

Generally, a waterfront is the zone of interaction between urban development and the water. A waterfront area is considered as a unique and irreplaceable natural resource. It is the interface between land, water, air, sun and productive plants (Wrenn, 1983). The seashore and riverfront are the most attractive water bodies for human settlement. In most countries, the land in front of water bodies is developed prior to the inland areas.

Waterfront development refers to any development in front of water bodies; river, lake, ocean, bay, creek or canal (Breen \& Rigby, 1994). In the development area, It is considered that a waterfront development may not necessarily need to be directly fronting water but may only need to be somewhat attached to the water (Breen \& Rigby, 1994; 1996). Properties with views towards water bodies are considered as waterfront properties.

\section{WATERFRONT DEVELOPMENT IN THIS RESEARCH}

In this research, waterfront development represents terms such as waterfront revitalisation, waterfront rehabilitation and other terminologies. The word redevelopment is only used when necessary; to differentiate between the redevelopment of previously built-up areas and new developments that are undertaken on a new development site. Waterfront development in this research refers particularly to any development in front of rivers. The exclusion of other waterfront development types such as the coastal development, is because the coastal zones are generally managed in a sectoral manner in Malaysia (Hussein, 2008; Zarin et al., 2001). The sectoral management approach is based on a tiered structure, between the Federal and State Government and Local Authorities. The 
governance in each level of government is responsible for their own management roles, which include performing planning and coordination, implementation and enforcement, and development roles within their jurisdictions.

\section{REGULATIONS RELATED TO WATERFRONT DEVELOPMENT IN MALAYSIA}

In most countries, various forms of regulations are implemented to improve physical, economic, social and spatial imbalances (Singh, 1994). In Malaysia, legislative systems are implemented within a broader framework and supervised by the federal government. Laws are also used as a form of management in response to environmental problems in Malaysia.

The importance of law, policies and guidelines towards waterfronts has been recognised in Malaysia as it has been in many countries (Riley \& ShurmerSmith, 1988). The earliest law in Malaysia which included the urban river aspect was introduced in 1907 and was known as the Sanitary Board Enactment (Latip et al., 2010). The Sanitary Board Enactment was focused on health and sanitation including drainage as part of the law. This enactment was later reviewed and renamed as the Municipal Ordinance Cap 133/1913, and the Town Improvement Enactment 1917. The development focused more on health and the habitation of houses (the setting of back lanes and open spaces for sanitary conveniences) (Norris, 1980). However, these new regulations did not specifically discuss rivers or the importance of them.

The specific law in relation to rivers was established in the 1920s and was known as the Water Act 1920. The Water Act 1920 provided a detailed definition of rivers, the responsible authority for the rivers and the riverbanks, and those involved in the appeal board (Water Act, 1920). The law remains to date and is used by the Department of Drainage and Irrigation of Malaysia (Malaysian Department of Irrigation and Drainage, 2009).

The first policy that stated the importance of waterfronts for public use was established in 1984 and was known as the Kuala Lumpur Structure Plan 1984 (Dewan Bandaraya Kuala Lumpur, 1984). The Kuala Lumpur Structure Plan provided specific concerns on developments around the natural features and including rivers. After that, several other initiatives directly and/or indirectly in relation to rivers and waterfronts were announced including the Malaysia Plan and the amendment of the Town and Country Planning Act 1976 in 1994. Despite the laws, various guidelines in relation to waterfronts were drafted by several department including guidelines for development related to rivers and river reserves as recreational areas (Malaysian Department of Irrigation and Drainage, 2006; National Landscape Department, 2005).

Presently, many laws, policies and guidelines that directly and/or indirectly relate to waterfronts are put in place. However, most of the laws established concentrate on penalties for the pollution of rivers rather than 
Azlina Md. Yassin, Md. Asrul Nasid Masrom, Mohd. Najib Mohd. Razali, \& Yasmin Mohd. Adnan

Policy Available and Sustainable Waterfront Development

specifically monitoring the importance of waterfronts. These laws include the Fishery Act (Act 317) (1985), the Environmental Quality Act (Act 127) (1974) and the Local Government Act (Act 171) (1976). The policies and guidelines introduced are very general and mostly enforced based on zoning rather than specific plots. For example, the National Urbanisation Policy by the Town and Country Planning Department. This has resulted in difficulties in monitoring and controlling development (Latip et al., 2010). Moreover, some of the guidelines are not gazetted and are only used in isolation within the department which produced them, such as the waterfront as recreational area by the National Landscape Department, the planning guidelines for river reserves as public open space by the Town and Country Planning Department and facing the river concept guidelines by the Drainage and Irrigation Department. This resulted to difficulties to implement the guidelines and discourage efforts to sustainable waterfront development (Latip et al., 2010).

\section{RESEARCH METHODOLOGY}

In this study, a quantitative research strategy was adopted. The survey was carried out within Malaysia and the respondents were property development companies listed under Bursa Malaysia. A stratified sampling procedure was used as part of probabilistic sampling (Sapsford \& Jupp, 2006; Sekaran, 2003).

The sample data comprised of firms listed under the property counter that traded at Bursa Malaysia. Considering that a waterfront development project requires strong financial records and sufficient and efficient management teams as well as excellent experiences in the past, the selection of property development companies who were listed in Bursa Malaysia was therefore appropriate. As stated by Bursa Malaysia, only 91 property development companies were listed in 2009.

\section{RESULTS AND DISCUSSION}

\section{Response Rate}

Out of 91 questionnaire forms mailed and e-mailed to the respondents, 61 forms were returned (67\% response rate). The respondents were mostly property development companies that have been actively practising property developments for many years and were listed in Bursa Malaysia. 
PLANNING MALAYSIA:

Journal of the Malaysia Institute of Planners (2018)

\section{Waterfront Development Practice in Malaysia}

From the results, nearly a third (32.8\%) of the property development companies undertook waterfront development projects in Malaysia, while the rest (67.2\%) were not involved in waterfront development in Malaysia or internationally. More than half $(58.6 \%)$ of the respondents were motivated to undertake waterfront development in the future, while the rest decided not to undertake waterfront development in the future and were not depending on the financial support or demands on waterfront property.

Moreover, from the $32.8 \%$ of respondents who undertake waterfront development, $75 \%$ of the development were for residential use, $70 \%$ were for mixed-use and $25 \%$ were for recreational purposes. The results also indicated that no companies undertake waterfront projects for industrial use, while 5\% undertake the waterfront projects for 'other' uses.

These findings were supported by the literature that indicated that in the past, many waterfront redevelopment areas went through a transition from abandoned spaces to commercial, residential and recreational areas (Bruttomesso, 1993; Butuner, 2006; Sairinen \& Kumpulainen, 2006). Moreover, previous research (Tumbde, 2005) also found that the riverfront redevelopment emphasizing on mixed-use developments enhance the economic feasibility of the redevelopment projects. In short, waterfront redevelopment projects were economically viable with implementation of mixed land use development during the redevelopment processes (Bruttomesso, 1993; Tumbde, 2005; Torre, 1989).

\section{Respondents' Level of Awareness towards Regulation for Waterfront Development in Malaysia}

The results indicated that overall property development companies were somewhat familiar with regulations related to waterfront development in Malaysia such as the National Land Code 1965 (mean score=3.59), the Town and Country Planning Act 1976 (mean score=3.57), the Building By-Law 1984 (mean score=3.56), the Land Acquisition 1960 (mean score=3.52) and guidelines for riverfront development (mean score $=3.05$ ) (just to name a few of the regulations and guidelines).

\section{Sufficiency of Regulations and Guidelines for Waterfront Development}

The results indicated that almost half $(44.3 \%)$ of the property development companies disagreed that Malaysia had sufficient regulations for waterfront development. The findings were consistent with previous studies (Latip et al., 2010) that revealed the reasons contributing to the loss of integration between cities and their water bodies in Malaysia. The reasons include the absence of policies and guidelines for waterfront development, the lack of policies and guidelines suitable for waterfront development and policies and guidelines 
Azlina Md. Yassin, Md. Asrul Nasid Masrom, Mohd. Najib Mohd. Razali, \& Yasmin Mohd. Adnan

Policy Available and Sustainable Waterfront Development

developed and implemented in isolation by different government agencies, and some guidelines that are not gazetted.

Subsequently, insufficient regulations and guidelines to control waterfront development in Malaysia and poor enforcement by the policy makers caused unsustainable waterfront development in Malaysia. These findings were supported by the literature that indicate that various forms of regulations were important for successful waterfront development (Riley \& Shurmer-Smith, 1988). In addition, adequate regulations and guidelines formulated for waterfront regeneration could have a significant impact upon waterfronts and enhance waterfront areas (Breen \& Rigby, 1996; West, 1989).

\section{ENFORCEMENT OF REGULATIONS FOR WATERFRONT DEVELOPMENT IN MALAYSIA}

From the results, only a quarter (24.6\%) of property development companies agreed that Malaysia enforces the regulations and guidelines for waterfront development sufficiently, while the rest believed that the guidelines were moderately enforced and were not enforced. The findings were consistent with previous studies (Latip et al., 2010) that showed that policies and guidelines developed and implemented in isolation by different government agencies. Additionally, some guidelines that were not gazette contributed to the loss integration between cities and their water bodies in Malaysia. Perhaps the Malaysian government and the responsible agencies need to strictly enforce the regulations to improve the sustainable waterfront development in Malaysia.

\section{CONCLUSION}

This paper identified and evaluated the regulations for waterfront development in Malaysia. The results concluded that Malaysia has insufficient number of regulations for controlling waterfront development. Moreover, the results also indicated that Malaysia has moderately enforced the regulations and guidelines developed for waterfront development. Surprisingly, some of the policies and guidelines were developed and implemented in isolation by different government agencies while some guidelines were not gazette. Therefore, sufficient number of regulation for controlling waterfront development as well as clear and coherent principles and policy are important in order to maximise the benefits of waterfront development (Riley \& Shurmer-Smith, 1988; Yossi \& Sajor, 2006). The guidelines and policies are also highly required in order to control waterfront development in Malaysia. 


\section{REFERENCES}

Ali, S. M., \& Nawawi, A. H. (2009, April). The social impact of urban waterfront landscapes: Malaysian perspectives. In 14th International Conference on Urban Planning, Regional Development and Information Society. April 22-25, 2009, Centre de Disseny de Sitges Catalonia/Spain.

Breen, A., \& Rigby, D. (1994). Waterfronts: Cities reclaim their edge. United State: McGraw-Hill.

Breen, A., \& Rigby, D. (1996). The new waterfront: A worldwide urban success story. New York: McGraw-Hill.

Bruttomesso, R. (1993). Working on the water's edge. In R. Bruttomesso (Ed.), Waterfronts - A new frontier for cities on water (pp. 10-11). Venice: International Center Cities on Water.

Butuner, B. (2006). Waterfront revitalisation as a challenging urban issue in Istanbul. 42nd ISoCaRP Congress: Waterfront Revitalisation as a Challenging Urban Issue. Spain.

Dewan Bandaraya Kuala Lumpur (1984). Kuala Lumpur Structure Plan. Kuala Lumpur: Kuala Lumpur City Hall.

Hussein, J. (2008, December). Opportunities and challenges in sustainable construction. International Conference and Expo on Environment Management and Technologies (ICEEMAT 2008). December 10-12, 2008, Kuala Lumpur, Malaysia.

Latip, N. S. A., Heath, T., Shamsuddin, S., Liew, M. S., \& Vallyutham, K. (2010, June). The contextual integration and sustainable development of Kuala Lumpur's city centre waterfront: An evaluation of the policies, law and guidelines. The World, Engineering, Science and Technology Congress (ESTCON 2010). June 15-17, 2010, Kuala Lumpur, Malaysia.

Malaysian Department of Irrigation and Drainage (2006). Guidelines for the development related to river and river reserves. Kuala Lumpur, Malaysia: Department of Irrigation and Drainage Malaysia.

Malaysian Department of Irrigation and Drainage (2009). Manual and guidelines for water management. Kuala Lumpur, Malaysia: Department of Irrigation and Drainage.

National Landscape Department (2005). Waterfront as recreational area. Kuala Lumpur, Malaysia: National Landscape Department, Ministry of Housing and Local Government Malaysia.

Norris, M. (1980). Local government in Peninsular Malaysia. Farnborough: Gower.

Riley, R., \& Shurmer-Smith, L. (1988). Global imperatives, local forces and waterfront redevelopment. In B. Hoyle, D. Pinder \& M. S. Husain (Eds.), Revitalising the waterfront: International dimensions of dockland redevelopment. London: Architectural Press Belhaven. 
Azlina Md. Yassin, Md. Asrul Nasid Masrom, Mohd. Najib Mohd. Razali, \& Yasmin Mohd. Adnan

Policy Available and Sustainable Waterfront Development

Sairinen, R., \& Kumpulainen, S. (2006). Assessing social impacts in urban waterfront regeneration. Environmental Impact Assessment Review, 26(1), 120-135.

Sapsford, R., \& Jupp, V. (2006). Data collection and analysis (2nd ed.). London: SAGE Publications.

Sekaran, U. (2003). Research methods for business: A skill building approach (4th ed.). New York: John Wiley \& Sons.

Singh, G. (1994). UMP - Asia occasional paper: Lands laws, land policies and planning in Malaysia: Urban Management Programme Regional Office for Asia - Pacific (UMP-Asia), retrieved 20th December, 2008, from www.kptg.gov.my.

Torre, L. A. (1989). Waterfront development. New York: Van Nostrand Reinhold.

Tumbde, D. (2005). Conceptual model for economically viable urban riverfront revitalization in United States (Master thesis). University of Cincinnati, USA.

West, N. (1989). Urban-waterfront developments: a geographic problem in search of a model. Geoforum, 20(4), 459-468.

Wrenn, D. M. (1983). Urban waterfront development. Washington, D.C.: The Urban Land Institute.

Yassin, M. A., (2012). Developing guidelines for riverfront development in Malaysia (Doctoral dissertation), Lincoln University, New Zealand.

Yossi, B., \& Sajor, E. E. (2006). Development of riverside kampung and management of rivers in Yogjakarta Indonesia: Issue of policy coherence and relevance of socio economic characteristics of river bank communities. Regional Conference on Urban Water and Sanitation in Southest Asean Cities. Vientiane, Laos PDR.

Zarin, D. J., Pereira, V. F. G., Raffles, H., Rabelo, F. G., Pinedo-Vasquez, M., \& Congalton, R. G. (2001). Landscape change in tidal floodplains near the mouth of the Amazon River. Forest Ecology and Management, 154(3), 383-393. 